\title{
Digestible lysine effects on gene expression by Japanese quails in the pre-laying phase
}

\author{
T.P. Santana ${ }^{1}$, E. Gasparino ${ }^{3}$, M.S. Bastos ${ }^{1}$, A.S. Lima ${ }^{1}$, A.P.G. Pinto ${ }^{2}$, G.M. Oliveira Junior ${ }^{1}$, \\ C.O. Brito ${ }^{1}$, L.T. Barbosa ${ }^{1}$ \& A.P. Del Vesco ${ }^{1 \#}$ \\ ${ }^{1}$ Department of Animal Science, Universidade Federal de Sergipe, São Cristóvão, Sergipe, Brazil \\ ${ }^{2}$ Department of Animal Science, Universidade Federal Rural de Pernambuco, Serra Talhada, Pernambuco, Brazil \\ ${ }^{3}$ Department of Animal Science, Universidade Estadual de Maringá, Avenida Colombo, Maringá, Paraná, Brazil
}

(Received 1 October 2018; Accepted 18 October 2019; First published online 31 January 2020)

\author{
Copyright resides with the authors in terms of the Creative Commons Attribution 4.0 South African Licence. \\ See: http://creativecommons.org/licenses/by/4.0/za \\ Condition of use: The user may copy, distribute, transmit and adapt the work, but must recognise the authors and the South African \\ Journal of Animal Science.
}

\begin{abstract}
This study aimed to determine the effects of digestible lysine levels in the diets of Japanese quail (Coturnix coturnix japonica) on performance, blood parameters and the expression of insulin-like growth factor I, and growth hormone receptor (GHR), apolipoprotein A-I (APOA-I), acetyl-CoA-carboxylase (ACC), and fatty acid synthase (FAS) genes. A total of 288 seven-day-old female Japanese quails were randomly assigned to one of three diets that contained $0.8 \%, 1.10 \%$, or $1.40 \%$ digestible lysine. The birds were slaughtered at 42 days old, and relative gene expression was evaluated in the liver by qRT-PCR using the $2^{-}$ ${ }_{\triangle \mathrm{CT}}$ method. Lysine supplementation had no effect on weight gain and feed conversion. Abdominal fat was lower in birds supplemented with $0.8 \%$ digestible lysine than those supplemented with $1.10 \%$ and $1.40 \%$. Increased total cholesterol and triglycerides were elevated in quails that received supplementation of $1.10 \%$ digestible lysine compared with the other diets. High density lipoproteins were decreased in birds that received $0.8 \%$ digestible lysine. Quails fed with $1.40 \%$ digestible lysine had greater expression of $G H R$ and APOA-I than quails fed diets with 0.8 and $1.10 \%(P<0.05)$. The greatest expressions of $A C C$ and $F A S$ were observed in the liver of quails fed with $0.8 \%$ digestible lysine. The current results suggest that lysine supplementation in the pre-laying phase allows birds to deposit muscle mass to reach the optimal conformation and body fatness that provides an energetic reserve for the productive phase by modulating the expression of genes related to growth and lipid metabolism.
\end{abstract}

Keywords: Coturnix coturnix japonica, growth, growth hormone, lipid synthesis, lipid metabolism

${ }^{\#}$ Corresponding author: apaulavesco@gmail.com

\section{Introduction}

In Japanese quail (Coturnix coturnix japonica), egg production begins around 42 days old, when birds reach sexual maturity (Camci et al., 2002). The growth phase is important to ensure good productivity and to achieve adequate body development for the beginning of the laying phase. Hormones such as insulin-like growth factor I (IGF-I) and growth hormone (GH) are fundamental to growth and development and reproductive maturity in birds (Fu et al., 2001; Pirsaraei et al., 2008). Growth hormone promotes oocyte maturation and the growth of preantral follicles (Silva et al., 2009). IGFs act in production and regulation of steroid hormones, cell proliferation and differentiation, inhibition of apoptosis and selection of follicles, and enhance the effects of luteinizing hormone (LH) and follicle stimulating hormone (FSH) on progesterone secretion (Onagbesan et al., 2009).

A balanced diet optimizes nutrient utilization and is essential for proper animal development and greater productive efficiency. In this context, amino acids such as lysine play a primary role in animal metabolism because they are involved in important metabolic pathways. Lysine is considered an essential amino acid, and lysine deficiency can cause damage related to muscle development and inhibit performance and growth in birds (Tesseraud et al., 2008).

While the supplementation of amino acids such as lysine (Kakhki et al., 2016) and methionine (Sumiati \& Wiryawan, 2016) can result in improved feed efficiency and egg production, nutritional imbalances in the 
growth phase can cause greater deposition of adipose tissue, which can affect productivity directly (Xing et al., 2009). The deposition of adipose tissue is characterized by excess lipids in the body as a result of the formation of adipocytes and cellular accumulation of triacylglycerol inside lipid droplets (Wang et al., 2017). In birds, the accumulation of fat, mainly in the abdominal cavity, affects the production of eggs negatively, with consequent economic losses (Ferreira et al., 2014). Conversely, prior to the laying phase, deposition of some fat can compensate for the greater energy requirements that occur during the production period (Neme et al., 2006).

Appropriate composition of the diet may offer a practical and efficient solution for reducing body fat deposition and improving growth in poultry (Fouad \& El-Senousey, 2014). Therefore, this study was designed to evaluate the effect of dietary digestible lysine concentrations on growth, plasma constituents and expression of IGF-I, GHR, apolipoprotein A-I (APOA-I), acetyl-CoA-carboxylase (ACC), and fatty acid synthase (FAS) genes in the livers of Japanese quails at 42 days old.

\section{Material and Methods}

The Committee on Animal Care of the Universidade Federal de Sergipe, Brazil, approved this study (protocol no 07/2015).

A total of 288 female Japanese quails (Coturnix coturnix japonica) at seven days old were used in this experiment. The animals were randomly assigned to one of three treatments that varied the lysine concentration, namely $0.80 \%, 1.10 \%$, and $1.40 \%$. Diets were formulated to meet the nutritional requirements of birds, except for lysine concentration (Rostagno et al., 2011) (Table 1). The animals were separated in collective cages (24 animals per cage), which served as the experimental units $(n=4)$ and were raised under conventional production systems. Throughout the experimental period, the birds were fed with feed and clean cool water ad libitum.

The quail were weighed, and feed intake was recorded every week determine bodyweight gain (BWG), and feed conversion ratio (FCR) (feed: gain) in the period (7 - 42 days). Mortality was recorded as it occurred.

All animals were slaughtered by cervical dislocation at 42 days old. The liver, breasts and abdominal fat of six animals from each treatment were weighed to obtain the proportional organ weights, which were calculated as (organ weight/bird weight) $\times 100$.

Blood was collected from five animals per treatment to evaluate the activity of aspartate aminotransferase (AST), alanine aminotransferase (ALT) and gamma-glutamyl transferase (GGT) enzymes and the amounts of total cholesterol, creatinine, triglycerides, very low density lipoprotein (VLDL), and high density lipoprotein (HDL) in the serum. The blood was collected from the jugular vein into glass tubes and kept on ice. After centrifugation (ThermoFisher Scientific, Waltham, MA) $\left(1500 \times \mathrm{g}, 10 \mathrm{~min}, 4^{\circ} \mathrm{C}\right)$, the serum was collected and stored at $-20^{\circ} \mathrm{C}$ until further analyses.

Determination of creatinine, total cholesterol, triglycerides, VLD, and HDL content and the ALT, AST, and GGT levels were based on standardized colorimetric methods with these kits: creatinine-MS 80022230066; total cholesterol PP-MS-80022230064; cholesterol HDL-PP-MS 800222300068, triglyceridesPP-MS 80022230062, ALT-MS 80022230086, AST-MS80022230083 and GAMA GT PP-MS80022230076, respectively (Gold Analisa, Belo Horizonte, Minas Gerais, Brazil).

For the analyses of gene expression levels, samples were taken from five birds from each treatment, chosen on the basis of the average bodyweight of each replicate. About $300 \mathrm{mg}$ of tissue from the right lobe of the liver was collected and stored in an RNA holder (BioAgency Biotecnologia, São Paulo, Brazil) at -20 ${ }^{\circ} \mathrm{C}$ until total RNA was extracted.

Total RNA was extracted from $100 \mathrm{mg}$ of sample using Trizol ${ }^{2}$ (Invitrogen, Carlsbad CA, USA) according to the manufacturer's instructions. All the materials had been treated with the RNase inhibitor RNase Away ${ }^{\circledR}$ (Invitrogen, Carlsbad, CA, USA). The tissue and TRIzol mixtures were triturated with a Polytron electric homogeniser until they were completely dissociated. Next, $200 \mu \mathrm{L}$ of chloroform was added to the sample, and the mixture was homogenized manually for $1 \mathrm{~min}$. The samples were then centrifuged for 15 min at $12000 \times \mathrm{g}$ at $4{ }^{\circ} \mathrm{C}$. The aqueous phase was collected and transferred to a clean tube containing $500 \mu \mathrm{L}$ of isopropanol per tube and again homogenized and centrifuged for $15 \mathrm{~min}$ at $12000 \times \mathrm{g}$ at $4{ }^{\circ} \mathrm{C}$. The supernatant was discarded, and the precipitate was washed in $1 \mathrm{~mL}$ of $75 \%$ ethanol. The material was once again centrifuged at $12000 \times \mathrm{g}$ for $5 \mathrm{~min}$, and the supernatant was discarded. The pellet was dried for 15 min and re-suspended in ultrapure RNase-free water. The total RNA concentration was measured using a spectrophotometer at a wavelength of $260 \mathrm{~nm}$. The RNA integrity was analysed using a 1\% denaturing agarose gel that was stained with $S Y B R{ }^{\circledR}$ Safe DNA gel stain (Invitrogen, Carlsbad, CA, USA) and visualized under ultraviolet light for checking the $18 \mathrm{~S}$ and $28 \mathrm{~S}$ ribosomal RNA bands. All the samples presented intact RNA samples. Next, the RNA samples were treated with DNase I (Invitrogen, Carlsbad, CA, USA) according to the manufacturer's instructions to remove potential genomic DNA contamination. 
Table 1 Percentage composition and nutritional values of experimental diets for Japanese quails in the prelaying phase

\begin{tabular}{|c|c|c|c|}
\hline \multirow{2}{*}{ Ingredient } & \multicolumn{3}{|c|}{ Digestible lysine levels, $\%$} \\
\hline & 0.8 & 1.10 & 1.40 \\
\hline Corn & 56.000 & 56.000 & 56.000 \\
\hline Soybean meal & 22.220 & 22.220 & 22.220 \\
\hline Wheat bran & 2.800 & 2.800 & 2.800 \\
\hline Vitamin and mineral mixture ${ }^{*}$ & 5.000 & 5.000 & 5.000 \\
\hline Corn gluten & 12.000 & 12.000 & 12.000 \\
\hline Salt & 0.399 & 0.399 & 0.399 \\
\hline Vegetable oil & 0.137 & 0.137 & 0.137 \\
\hline L-Lysine HCL & - & 0.385 & 0.769 \\
\hline DL-Methionine & - & - & 0.136 \\
\hline L-Threonine & - & 0.041 & 0.258 \\
\hline Inert & 1.444 & 1.018 & 0.280 \\
\hline \multicolumn{4}{|l|}{ Energy and nutritional composition } \\
\hline Metabolizable energy, Kcal/kg & 2900 & 2900 & 2900 \\
\hline Crude protein, $\%$ & 22.23 & 22.23 & 22.23 \\
\hline Calcium, $\%$ & 0.928 & 0.928 & 0.928 \\
\hline Available phosphorus, $\%$ & 0.424 & 0.424 & 0.424 \\
\hline Sodium, \% & 0.176 & 0.176 & 0.176 \\
\hline \multicolumn{4}{|l|}{ Digestible amino acids, \% } \\
\hline Methionine + cysteine & 0.818 & 0.818 & 0.952 \\
\hline Lysine & 0.800 & 1.100 & 1.400 \\
\hline Threonine & 0.741 & 0.781 & 0.994 \\
\hline Tryptophan & 0.200 & 0.200 & 0.200 \\
\hline
\end{tabular}

A SuperScript ${ }^{\mathrm{TM}}$ III first-strand synthesis super mix (Invitrogen Corporation, Brazil) kit was used for cDNA synthesis from $1 \mu \mathrm{g}$ of DNase-treated total RNA, according to the manufacturer's instructions. For this reaction, $1 \mu \mathrm{g}$ of DNase-treated total RNA, $1 \mu \mathrm{L}$ of oligo dT (50 $\mu \mathrm{M}$ oligo(dT)20) and $1 \mu \mathrm{L}$ of annealing buffer were added to a sterile RNA-free tube. The reaction was then incubated for $5 \mathrm{~min}$ at $65^{\circ} \mathrm{C}$ and placed on ice for $1 \mathrm{~min}$. Subsequently, $10 \mu \mathrm{L}$ of $2 \times$ first-strand reaction mix and $2 \mu \mathrm{L}$ of solution containing SuperScript III reverse transcriptase enzyme and RNase inhibitor were added to the tubes. The solution was incubated for 50 min at $50{ }^{\circ} \mathrm{C}$ for the synthesis of complementary DNA. Next, the reaction was incubated for 5 min at 85 ${ }^{\circ} \mathrm{C}$ and immediately placed on ice. The cDNA concentration was measured with a spectrophotometer at a wavelength of $260 \mathrm{~nm}$. The cDNA samples were diluted to $40 \mathrm{ng} / \mu \mathrm{L}$ and stored at $-20^{\circ} \mathrm{C}$ until further use as template in the amplification reaction.

The primers that were used for this study were obtained from previous works of Del Vesco et al. (2015) (IGF-I and GHR genes), Jiang et al. (2014) (APOAI gene), and Lei and Lixian (2012) (ACC and FAS genes). Amplicon of each primer set was evaluated by Sanger sequencing and the specificity of each primer was checked using primer BLAST program. The $\beta$-actin gene was used as the housekeeping gene (Table 2). 
Table 2 Primer sequences used for quantitative real-time polymerase chain reaction

\begin{tabular}{lccc}
\hline Gene & Amplicon, $\mathrm{pb}^{*}$ & Primer sequence (5'-3') & Reference \\
\hline IGF-I ${ }^{\dagger}$ & 140 & F:CACCTAAATCTGCACGCT & Rel Vesco et al. (2015) \\
& 145 & F:CACACAGATACCCAACAGCC & Del Vesco et al. (2015) \\
RHR & 217 & R:AGAAGTCAGTGTTTGTCAGGG & Jiang et al. (2014) \\
APOA-I & 136 & R:CACTCAGCGTGTCCAGGTTGT & Lei \& Lixian (2012) \\
ACC & 107 & F:AATGGCAGCTTTGGAGGTGT & Lei \& Lixian (2012) \\
FAS & R:TCTGTTTGGGTGGGAGGTG & Del Vesco et al. (2015)
\end{tabular}

*Amplicon size in base pairs

${ }^{\dagger}$ Insulin-like growth factor I (IGF-I) growth hormone receptor (GHR), apolipoprotein A-I (APOA-I), acetyl-CoA-carboxylase (ACC) and fatty acid synthase (FAS)

Real-time PCR reactions were performed using the fluorescent dye SYBR GREEN (SYBR® GREEN PCR Master Mix, Applied Biosystems, USA). The amplification reaction consisted of $5 \mu \mathrm{L}$ of diluted CDNA, $0.5 \mu \mathrm{L}$ of each primer (forward and reverse) at $10 \mu \mathrm{M}$ (final concentration $200 \mathrm{nM}$ ), $12.5 \mu \mathrm{L}$ of SYBR ${ }^{\circledR}$ GREEN PCR Master Mix, and water to a total volume of $25 \mu \mathrm{L}$. The thermal cycling parameters for all genes consisted of hot start at $95{ }^{\circ} \mathrm{C}$ for $10 \mathrm{~min}$, followed by 40 cycles of denaturation at $95{ }^{\circ} \mathrm{C}$ for 15 seconds and annealing/extension at $60^{\circ} \mathrm{C}$ for $1 \mathrm{~min}$, ending with a melt curve from 65 to $95^{\circ} \mathrm{C}$. All of the analyses were performed in duplicate. To measure the efficiency of each primer/gene set, a series of $25 \mu \mathrm{L}$ reactions was analysed as described above using $5 \mu \mathrm{L}$ of a serial dilution of pooled CDNA as the template. The efficiency was calculated using the slope produced by each qPCR standard curve using the formula:

$$
\text { Efficiency }=-1+10^{(-1 / \text { slope })} \text {. }
$$

The $2^{-\Delta C T}$ method (Livak \& Schmittgen, 2001) was used to analyse relative expression. The results are expressed as means and standard errors. The Shapiro-Wilk test was applied to evaluate the normality of the data. The data were submitted to one-way ANOVA. When the effect was significant, the means were compared with Tukey's test $(P<0.05)$ (SAS Inst. Inc. Cary, NC, USA).

\section{Results}

The effects of digestible lysine levels on performance and the proportional weights of the liver, abdominal fat, and breast are shown in Table 3. Lysine supplementation $(P=0.009)$ increased the percentage of abdominal fat. The treatments did not influence weight gain and feed conversion.

The lysine level affected total cholesterol $(P=0.0048)$, triglycerides $(P=0.0305)$, HDL $(P=0.0487)$, and VLDL $(P=0.0063)$ significantly. The highest total cholesterol, VLDL and triglycerides contents were observed in quails fed diets with $1.10 \%$ digestible lysine. The lowest HDL content was observed in birds that received diets with $0.8 \%$ digestible lysine (Table 4 ). 
Table 3 Weight gain, feed conversion and proportional weights of breast, liver and abdominal fat (mean \pm SE) from Japanese quails at 42 days old fed diets that differ in level of supplemental lysine

\begin{tabular}{lcccc}
\hline & \multicolumn{3}{c}{ Digestible lysine level, \% } & $P$-value \\
\cline { 2 - 4 } \multicolumn{1}{c}{ Trait } & 0.8 & 1.10 & 1.40 & 0.1051 \\
Weight gain, g & $138.830 \pm 1.792$ & $143.194 \pm 2.306$ & $144.730 \pm 1.764$ & 0.0519 \\
Feed conversion, g/g & $3.295 \pm 0.043$ & $3.419 \pm 0.044$ & $3.448 \pm 0.046$ & 0.3233 \\
Breast, \% & $20.929 \pm 0.448$ & $20.222 \pm 0.718$ & $22.123 \pm 0.044$ & 0.7054 \\
Liver, \% & $0.885 \pm 0.048$ & $0.969 \pm 0.041$ & $0.948 \pm 0.033$ & 0.0009 \\
Abdominal fat, \% & $0.154^{\mathrm{b}} \pm 0.011$ & $0.473^{\mathrm{a}} \pm 0.036$ & $0.342^{\mathrm{a}} \pm 0.005$ & \\
\hline a,b & & & & \\
\end{tabular}

Table 4 Serum enzymes and lipid profile (mean \pm SE) from Japanese quails at 42 days old fed diets that differed in level of supplemental lysine

\begin{tabular}{lcccc}
\hline & \multicolumn{3}{c}{ Digestible lysine level, $\%$} & $P$-value \\
\cline { 2 - 4 } Serum constituents ${ }^{1}$ & 0.8 & 1.10 & 1.40 & 0.0675 \\
GGT & $4.750 \pm 1.25$ & $3.650 \pm 0.62$ & $1.650 \pm 0.23$ & 0.1048 \\
AST & $382 \pm 117.96$ & $169 \pm 2.66$ & $192 \pm 10.63$ & 0.1827 \\
ALT & $3.812 \pm 1.24$ & $3.937 \pm 1.44$ & $1.062 \pm 0.46$ & 0.0048 \\
TC & $190.50^{\mathrm{b}} \pm 12.87$ & $379.50^{\mathrm{a}} \pm 42.72$ & $225.25^{\mathrm{b}} \pm 31.28$ & 0.2483 \\
Cr & $0.287 \pm 0.04$ & $0.275 \pm 0.048$ & $0.200 \pm 0.01$ & 0.0305 \\
TGR & $612.25^{\mathrm{b}} \pm 42.98$ & $1513.50^{\mathrm{a}} \pm 375.74$ & $345.50^{\mathrm{b}} \pm 69.46$ & 0.0487 \\
HDL & $47.00^{\mathrm{b}} \pm 3.83$ & $71.50^{\mathrm{a}} \pm 5.85$ & $67.50^{\mathrm{a}} \pm 8.45$ & 0.0063 \\
VLDL & $122.50^{\mathrm{b}} \pm 8.58$ & $369.50^{\mathrm{a}} \pm 40.72$ & $345.50^{\mathrm{ab}} \pm 137.70$ &
\end{tabular}

$\overline{\mathrm{a}, \mathrm{b}}$ Mean values within a row with unlike superscripts were significantly different by Tukey's test $(P<0.05)$.

${ }^{1}$ GGT: gamma-glutamyl transferase (U/L); AST: aspartate aminotransferase (U/L); ALT: alanine aminotransferase (U/L); TC: total cholesterol (mg/dL); Cr: creatinine (mg/dL); TGR: triglycerides (mg/dL); HDL: high density lipoprotein (mg/dL); VLDL: very low density lipoprotein $(\mathrm{mg} / \mathrm{dL})$

The amplification efficiencies (90\% to $110 \%$ ) were similar for the genes of interest and the housekeeping gene. Analysis of the dissociation curves did not reveal non-specific PCR products, such as the formation of primer dimers, thus demonstrating the reliability of the data for estimating the mRNA expression of these genes. The endogenous control $\beta$-actin did not show significant differences among treatments, which confirmed its suitability as a control.

Table 5 shows the gene expression results in the liver. A significant effect of digestible lysine levels on GHR ( $P=0.0023), A P O A-I(P=0.0484), A C C(P=0.0448)$, and $F A S(P=0.0319)$ gene expressions was observed. Greater relative gene expression levels (AU) for GHR and APOA-I were observed in the liver of quails fed with $1.40 \%$ digestible lysine (13.768 and $8697.48 \mathrm{UA}$, respectively). There was no significant difference in the expression of these genes between animals fed with 0.8 and $1.10 \%$ digestible lysine.

Quails fed diets with $0.8 \%$ digestible lysine had the highest expression of the ACC and FAS genes (15.78 and $7.74 \cup A$, respectively).

There was no treatment effect on IGF-I gene expression. 
Table 5 Relative gene expression levels (Mean \pm SE) in liver of Japanese quails at 42 days old fed diets that differed in level of supplemental lysine

\begin{tabular}{|c|c|c|c|c|}
\hline \multirow{2}{*}{ Gene $^{1}$} & \multicolumn{3}{|c|}{ Digestible lysine level, \% } & \multirow{2}{*}{$P$-value } \\
\hline & 0.8 & 1.10 & 1.40 & \\
\hline IGF-I & $0.756 \pm 0.31$ & $0.443 \pm 0.16$ & $0.882 \pm 0.27$ & 0.4827 \\
\hline GHR & $3.387^{\mathrm{b}} \pm 0.45$ & $4.380^{b} \pm 0.54$ & $13.768^{\mathrm{a}} \pm 3.15$ & 0.0023 \\
\hline APOA-I & $3756.73^{\mathrm{b}} \pm 143.92$ & $3218.58^{\mathrm{b}} \pm 730.45$ & $8697.48^{a} \pm 2603.41$ & 0.0484 \\
\hline$A C C$ & $15.779^{\mathrm{a}} \pm 5.64$ & $2.426^{\mathrm{b}} \pm 0.72$ & $7.461^{\mathrm{ab}} \pm 1.74$ & 0.0448 \\
\hline FAS & $7.739^{\mathrm{a}} \pm 1.79$ & $1.413^{\mathrm{b}} \pm 0.49$ & $2.183^{\mathrm{b}} \pm 0.44$ & 0.0319 \\
\hline
\end{tabular}

\footnotetext{
${ }^{a, b}$ Mean values within a row with unlike superscript letters were significantly different by Tukey's test $(P<0.05$.

${ }^{1}$ IGF-I: Insulin-like growth factor; GHR: growth hormone receptor; APOA-I: apolipoprotein A-I; ACC: acetyl-CoAcarboxylase; FAS: fatty acid synthase.
}

\section{Discussion}

To start the production phase, birds must reach adequate weight and body conformation. In this prelaying phase, proper development is necessary, particularly in the immune and digestive systems, and muscle and fat deposition must take place in appropriate proportions (Kaplan \& Gürcan, 2016). Deposition of muscle mass occurs as a function of the balance between factors that promote protein synthesis and those that stimulate protein degradation. Protein synthesis is linked to the action of growth-related hormones, including IGF-I and GH. The metabolic pathway triggered by the action of IGF-I is composed of several factors that result in the activation of the mechanistic target of rapamycin (mTOR). As a key protein in cellular physiology, mTOR regulates several components that are involved in protein synthesis, including initiation and elongation factors and ribosome production (Wang \& Proud, 2006).

Several studies (Swennen et al., 2007; Ghazanfari et al., 2010; Kini et al., 2016) have shown the influence of diet on the expression of these factors. In this study, birds that received a diet with a higher level of lysine had greater GHR expression. A deficiency of a specific amino acid may be related to lower protein deposition or reduced growth performance (Tesseraud et al., 2007; Del Vesco et al., 2015). Among the amino acids provided to birds, lysine is responsible for the deposition of body protein, and may compromise performance when supplied below the recommended level (Zhai et al., 2016). This result may be associated with the greater action of genes related to proteolysis in the muscle of birds fed a lower level of lysine (Tesseraud et al., 2008), or be due to the lower expression of genes related to synthesis similar to that observed in this study.

Amino acids are related to various pathways and mechanisms to stimulate protein deposition and to improve growth and reproduction of animals (Wu, 2010). Their deficiency can result in poor performance and delayed development of immune-system organs (Mulyantini, 2014). In this study, the activities of AST, ALT and GGT enzymes as possible physiological markers of damage were evaluated, since high levels of these enzymes may be associated with acute liver diseases (Georgakouli et al., 2015). The lack of effect of the current treatments on the activity of these enzymes suggests that there was no damage to the liver in these quail.

Lysine is also responsible for the synthesis of carnitine. Carnitine acts in transport of fatty acids into mitochondria where lipid oxidation occurs in response to a demand for energy by the organism (Botham \& Mayes, 2015). For pre-laying birds, lipids are important for the synthesis of reproduction-related hormones and for maintaining the integrity of cell membranes and are essential for ensuring sexual maturation. At this phase, there is a greater synthesis of lipids, since the birds are preparing for a demanding period of egg production. The liver is the primary site for lipogenesis and during this phase, the liver acts as a secondary sex organ, producing two of the main precursors of yolk, vitellogenin and very low-density lipoprotein (VLDL) (Xu et al., 2003; Wu et al., 2013).

In the liver, the process of fatty acid synthesis is performed in a sequence of reactions. It begins with the formation of malonyl-CoA from acetyl-CoA when it is catalysed by the enzyme acetyl-CoA-carboxylase (ACC). By the action of ACC, acetyl-CoA is converted to malonyl-CoA, which is transformed by FAS into palmitate, which is an important precursor in the synthesis of long chain saturated fatty acids (Nelson \& Cox, 2011). Production of both ACC and FAS is influenced by several factors, such as the availability of energy, insulin levels and protein kinases (Zhou et al., 2001). 
In the bloodstream, lipids are transported to the liver with the help of apolipoproteins, and form the lipoproteins HDL, LDL, IDL, VLDL, and portomicrons. Among the apolipoproteins, apolipoprotein A-I acts as the main protein constituent of HDL. APOA-I together with HDL promotes the removal of cholesterol from extrahepatic peripheral cells to the liver (Zannis et al., 1983; Fielding \& Fielding, 1995; Spady, 1999). Thus, lower expression of the APOA-I gene is believed to be related to greater accumulation of abdominal fat in birds (Zhuo et al., 2015).

Nutrients in the diet of birds affect the expression of ACC, FAS, and APOA-I genes (Bastos et al., 2017). In addition, increased crude protein (CP) and amino acid supplementation at appropriate levels can reduce the expression of genes that are involved in lipogenesis because greater $\mathrm{CP}$ in the diet is related to reduced expression of the $A C C$ and FAS genes, consequently reducing the size of adipocyte cells, which are responsible for the deposition of abdominal fat (Rosebrough et al., 2008, 2011; Wu et al., 2011; Fouad et al., 2013).

Previous studies have shown that lower expression of the ACC and FAS (Wu et al., 2011) and greater expression of APOA-I (Zhuo et al., 2015) genes are related to reduced deposition of abdominal fat. However, it was observed in this study that birds fed a diet with higher levels of lysine had reduced expression of $A C C$ and FAS, increased expression of APOA-I, and a greater deposition of abdominal fat. These contrasting results may be related to changes in the metabolism of birds during their development. After reaching a certain weight (or degree of maturity), birds gradually direct more ingested energy to fat deposition, which will act as the energy reserve that is necessary for the beginning of reproductive life (Neme et al., 2006). Thus, fat deposited in the abdominal cavity during the growth phase can be used as an energy reserve in the laying phase. Accordingly, the higher content of total cholesterol and serum triglycerides that the authors observed in birds fed higher levels of lysine may suggest that fat stored in adipose tissue is being directed to the liver. Fat that comes into the liver in the form of HDL will be metabolized and, after synthesis of the precursors of the yolk, will be transported to the ovary, mainly in the form of VLDL, to support egg production. In this study, a higher VLDL content was observed in birds that received diets with lysine supplementation.

\section{Conclusion}

Lysine supplementation in the pre-laying phase may allow quail to deposit muscle mass to reach optimal conformation, as well as body fat that will be used as an energy reserve in the productive phase by modulating the expression of genes related to growth and lipid metabolism.

\section{Acknowledgements}

This study was supported by the National Council for Scientific and Technological Development (CNPq). This study was financed in part by the Coordenação de Aperfeiçoamento de Pessoal de Nível Superior - Brasil (CAPES) Finance Code 001.

\section{Authors' Contributions}

TPS and APDV wrote the manuscript; EG, MSB, ASL, APGP, GMOJ, COB and LTB revised the manuscript; GMOJ and APDV designed the experiment; ASL, COB and GMOJ conducted the animal experiment; MSB conducted the laboratory analysis; TPS performed gene expression analysis; EG and APGP analysed the data; LTB and APDV secured funding for the project. All authors proofread and approved the final manuscript.

\section{Conflict of Interest Declaration}

The authors declare they have no competing interests.

\section{References}

Bastos, M.S., Del Vesco, A.P., Santana, T.P., Santos, T.S., Oliveira Junior, G.M., ..., Gasparino, E., 2017. The role of cinnamon as a modulator of the expression of genes related to antioxidant activity and lipid metabolism of laying quails. PLOS. https://doi.org/10.1371/journal.pone.0189619

Botham, K.M. \& Mayes, P.A., 2015. Oxidation of fatty acids: Ketogenesis. In: V. Rodwell, D. Bender, K.M. Botham, P.J. Kennelly \& P.A. Weil. (eds). Harper's illustrated biochemistry. pp. 223. McGraw-Hill Education, New York.

Camci, O., Erensayin, C. \& Aktan, S., 2002. Relations between age at sexual maturity and some production characteristics in quails. Arch. Geflugelk. 66, 280-282.

Del Vesco, A.P., Gasparino, E., Grieser, D.O., Zancanela, V., Voltolini, D.M., ..., Oliveira, A.R.N., 2015. Effects of methionine supplementation on the expression of protein deposition-related genes in acute heat stress-exposed broilers. PLOS. DOI: https://doi.org/10.1371/journal.pone.0115821

Ferreira, P.B., Favero, A., Rosa, A.P., Macedo, A., Taschetto, D. \& Barbosa, J.G.M., 2014. Follicular development and productive performance at the onset of production in two egg-laying breeds. Ciência Rural. DOI: http://dx.doi.org/10.1590/S0103-84782014000300026

Fielding, C.J. \& Fielding, P.E., 1995. Molecular physiology of reverse cholesterol transport. J. Lipid. Res. 36, $211-228$. 
Fouad, A.M. \& El-Senousey, H.K., 2014. Nutritional factors affecting abdominal fat deposition in poultry: A review. AsianAustralas J. Anim. Sci. DOI:10.5713/ajas.2013.13702.

Foaud, A.M., El-Senousey, H.K., Yang, X.J. \& Yao, J.H., 2013. Dietary L-arginine supplementation reduces abdominal fat content by modulating lipid metabolism in broiler chickens. Animal 7, 1239-1245. DOI: https://doi.org/10.1017/S1751731113000347

Fu, Z., Kubo, T., Noguchi, T. \& Kato, H., 2001. Developmental changes in the mRNA levels of IGF-I and its related genes in the reproductive organs of Japanese quail (Coturnix coturnix japonica). Growth Horm. IGF Res. DOI: https://doi.org/10.1054/ghir.2000.0186

Georgakouli, K., Manthou, E., Fatouros, I.G., Deli, C.K., Spandidos, D.A., ..., Jumartas, A.Z., 2015. Effects of acute exercise on liver function and blood redox status in heavy drinkers. Exp. Ther. Med. DOI:10.3892/etm.2015.2792.

Ghazanfari, S., Kermanshahi, H., Nassiry, M.R., Golian, A., Moussavi, A.R.H. \& Salehi, A., 2010, Effect of feed restriction and different energy and protein levels of the diet on growth performance and growth hormone in broiler chickens. J. Biol. Sci. DOI: https://scialert.net/abstract/?doi=jbs.2010.25.30

Jiang, R.R., Zhao, J.P., Chen, J.L., Zheng, M.Q., Liu, R.R. \& Wen, J., 2014. Influence of dietary nicotinic acid supplementation on lipid metabolism and related gene expression in two distinct broiler breeds of female chickens. J. Anim. Physiol. Anim. Nutr. DOI: 10.1111/jpn.12138

Kaplan, S. \& Gürcan, E.K., 2016. Comparison of growth curves using non-linear regression function in Japanese quail. J. Appl. Anim. Res. DOI: https://doi.org/10.1080/09712119.2016.1268965

Kakhki, R.A.M., Goliano, A. \& Zarghi, H., 2016. Effect of dietary digestible lysine concentration on performance, egg quality, and blood metabolites in laying hens. JAPR. DOI: https://doi.org/10.3382/japr/pfw032

Kini, A., Fernandes, C. \& Suryawanshi, D., 2016. Effect of KiFAY on performance, insulin-like growth factor-1, and thyroid hormones in broilers. Asian-Australas. J. Anim. Sci. DOI: 10.5713/ajas.16.0188

Lei, L. \& Lixian, Z., 2012. Effect of $24 \mathrm{~h}$ fasting on gene expression of AMPK, appetite regulation peptides and lipometabolism related factors in the hypothalamus of broiler chicks. AJAS. DOI: 10.5713/ajas.2012.12153

Livak, K.J. \& Schmittgen, T.D., 2001. Analysis of relative gene expression data using realtime quantitative PCR and the $2 \Delta \Delta C(T)$. Methods 25, 402-408.

Mulyantini, N.G.A., 2014.The antibody and organ immune responses of broiler starter fed diets with graded levels of digestible lysine. Med. Pet. DOI: https://doi.org/10.5398/medpet.2014.37.1.57

Nelson, D.L. \& Cox, M.M., 2011. Lehninger principles of biochemistry. 5th edition. Worth, New York.

Neme, R., Sakomura, N.K., Fukayama, E.H., Freitas, E.R., Filho, F.B., Resende, K.T. \& Fernandes, J.B.K., 2006. Growth curves and deposition of body components in pullets of different strains. J. Anim. Sci. Technol. DOI: http://dx.doi.org/10.1590/S1516-35982006000400021

Onagbesan, O., Bruggeman, V. \& Decuypere, E., 2009. Intra-ovarian growth factors regulating ovarian function in avian species: A review. Anim. Reprod. Sci. DOI: https://doi.org/10.1016/j.anireprosci.2008.09.017

Pirsaraei, Z.A., Shahneh, A.Z., Zaghari, M., Zamiri, M.J. \& Mianji., 2008. Effect of testosterone and growth hormone injection before puberty on follicles size, rate of egg production and egg characteristics of the Mazandaran Native breeder hens. AJOL. 7, 3149-3154.

Rosebrough, R.W., Russell, B.A. \& Richards, M.P., 2008. Short term changes in the expression of lipogenic genes in broilers (Gallus gallus). Comp. Biochem. Physiol. A. Mol. Integr. Physiol. DOI: https://doi.org/10.1016/j.cbpa.2008.01.035.

Rosebrough, R.W., Russel, B.A. \& Richards, M.P., 2011. Further studies on short-term adaptations in the expression of lipogenic genes in broilers. Comp. Biochem. Physiol. A. Mol. Integr. Physiol. DOI: https://doi.org/10.1016/j.cbpa.2010.10.032.

Rostagno, H.S., Albino, L.F.T., Donzele, J.L., Gomes, P.C., Oliveira, R.F., .., Euclides, R.F., 2011. Brazilian tables for poultry and swine: Composition of feedstuffs and nutritional requirements. 3rd edition. Minas Gerais, BR.

Silva, J.R., Figueuredo, J.R. \& Van den Hurk, R., 2009. Involvement of growth hormone (GH) and 711 insulin-like growth factor (IGF) system in ovarian folliculogenesis. Theriog. DOI: https://doi.org/10.1016/j.theriogenology.2008.12.015

Spady, D.K., 1999. Reverse cholesterol transport and atherosclerosis regression. Circulation 100 (6). DOI: 10.1161/01.cir.100.6.576

Sumiati, A. \& Wiryawan, K.G., 2016. Egg quality and blood hematology of Magelang laying duck fed with diets containing different ratios of omega and omega fatty acids and organic Zn. Poult. Sci. DOI: 10.3923/ijps.2016.448.453

Swennen, Q., Decuypere, E. \& Buyse, J., 2007. Implications of dietary macronutrients for growth and metabolism in broiler chickens. Poult. Sci. DOI: https://doi.org/10.1017/S0043933907001602

Tesseraud, S., Métyer-Coustard, S., Boussaid, S., Crochet, S., Derouet, M. \& Seilliez, I., 2007. Insulin and amino acid availability regulate atrogin-1 in avian QT6 cells. Biochem. Biophys. Res. Commun. DOI: https://doi.org/10.1016/j.bbrc.2007.03.131

Tesseraud, S., Bouvarel, I., Collin, A., Audouin, E., Crochet, S., Seiliez, I. \& Leterrier, C., 2008. Daily variations in dietary lysine content alter the expression of genes related to proteolysis in chicken pectoralis major muscle. J. Nutr. DOI: https://doi.org/10.3945/jn.108.095752

Xing, J., Kang, L., Hu, Y., Xu, Q., Zhang, N. \& Jiang, Y., 2009. Effect of dietary betaine supplementation on mRNA expression and promoter CpG methylation of lipoprotein lipase gene in laying hens. Poult Sci. DOI: https://doi.org/10.2141/jpsa.46.224

Xu, Z.R., Wang, M.Q., Mao, H.X., Zhan, X.A. \& Hu, C.H., 2003. Effects of L-carnitine on growth performance, carcass composition, and metabolism of lipids in male broilers. J. Poult. Sci. DOI: https://doi.org/10.1093/ps/82.3.408

Wang, X. \& Proud, C.G., 2006. The mTOR pathway in the control of protein synthesis. Physiology. DOI: http://doi.org/10.1152/physiol.00024.2006 
Wang, G., Kim, W.K., Cline, M.A. \& Gilbert, E.R., 2017. Factors affecting adipose tissue development in chickens: A review. Poult. Sci. DOI: https://doi.org/10.3382/ps/pex184

Wu, G., 2010. Functional amino acids in growth, reproduction, and health. Adv. Nutr. DOI:10.3945/an.110.1008

Wu, F., FU, W., Huang,Y., Ni, Y. \& Zhao, R., 2013. Kisspeptin-10 enhanced egg production in quails associated with the Increase of triglyceride synthesis in liver. AJAS. DOI: 10.5713/ajas.2013.13014

Wu, L.Y., Fang, Y.J. \& Guo, X.Y., 2011. Dietary L-arginine supplementation beneficially regulates body fat deposition of meat-type ducks. Br. Poult. Sci. DOI: https://doi.org/10.1080/00071668.2011.559452

Zannis, V.I., Karathanasis, S.K., Keutmann, H.T., Goldberg, G. \& Breslow, J.L., 1983. Intracellular and extracellular processing of human apolipoprotein Al: Secreted apolipoprotein Al isoprotein 2 is a propeptide. Proc. Natl. Acad. Sci. DOI:10.1073/pnas.80.9.2574

Zhai, W., Schilling, M.W., Jackson, V. \& Mercier, Y., 2016. Effects of dietary lysine and methionine supplementation on Ross 708 male broilers from 21 to 42 days of age (II): Breast meat quality. J. Appl. Poult. Res. DOI: https://doi.org/10.3382/japr/pfw003

Zhou, G., Myers, R., Li, Y., Chen, Y., Shen, X., Fenky-Melody, J., ..., Moller, D.E., 2001. Role of AMP-activated protein kinase in mechanism of metformin action. J. Clin. Invest. DOI: 10.1172/JCI13505

Zhuo, Z., Lamont, S.J., Lee, W.R. \& Abasht, B., 2015. RNA-seq analysis of abdominal fat reveals differences between modern commercial broiler chickens with high and low feed efficiencies. PLOS. DOI: https://doi.org/10.1371/journal.pone.0135810 